\title{
Soybean Yield Gap Analysis through Front Line Demonstration in Satpura Plateau of Madhya Pradesh
}

\author{
R.L. Raut ${ }^{1}$, V.K. Verma $^{2}$, R.D. Barpete ${ }^{3}$, Sanjay Jain ${ }^{4}$ \\ ${ }^{1}$ I/c Programme Coordinator, KVK Balaghat, JNKVV, Jabalpur, India \\ ${ }^{2} \mathrm{I} / \mathrm{c}$ Programme Coordinator KVK Betul, JNKVV, MP, India \\ ${ }^{3}$ Scientist (Plant Protection) KVK Betul, JNKVV, MP, India \\ ${ }^{4}$ Programme Assistance. KVK Betul, JNKVV, MP, India
}

\begin{abstract}
Front line demonstration is an effective and appropriate tool to demonstrate recommended technologies among the farmers. Krishi Vigyan Kendra, Betul (M.P.) conducted 78 demonstrations on soybean since 2004-05 to 2009-10 in six adopted villages. The critical inputs were identified in existing production technology through farmers meeting and group discussion with the farmers. The six years data revealed that an average yield of demonstration plot was obtained 18.35 q/ha over local check (11.85 q/ha) with an additional yield of $6.5 \mathrm{q} / \mathrm{ha}$ and the increase average soybean productivity by $60.93 \%$. The average technologies gap and technological index were observed to be $11.65 \mathrm{q} / \mathrm{ha}$ and technological index $38.33 \%$ respectively.
\end{abstract}

Keywords-Krishi Vigyan Kendra, JNKVV, oil.

\section{INTRODUCTION}

India is the fourth largest producer of oilseed in the world and fifth largest producer of soybean in the world. Now a day's soybean is major oil seed crop of India. In India share of soybean in total oilseed is $25 \%$ and. The continuous increase in import of oilseed and oil is a matter of great concern in Indian oilseed scenario. In India during the year 2007-08 total area under soybean was 8880 thousand hectare and production is 9990 thousand tons with the productivity of $1124 \mathrm{~kg}$ per hectare.

Madhya Pradesh is known as "soybean state" due to highest production and acreage under soybean crop. The area under soybean cultivation in state is 6489.6 thousand hectares (2008-09) and the production is 6977 thousand tones with the productivity of $1075 \mathrm{~kg} / \mathrm{ha}$. Share of soybean in total oilseed production of the state is $53.7 \%$. Soybean crop having highest acreage is Kharif crop of the state but large yield gap exist between potential yield and yield under real farming.

Betul district is situated in Satpura plateau of M.P. More than $40 \%$ population of the district is tribal and soil type is also limiting factor for soybean cultivation. Soybean is major kharif crop of the district. The area under crop in district is 171.2 thousand hectare and production is 164.2 tones with the productivity of $959 \mathrm{~kg} / \mathrm{ha}(2007-08)$. The poor productivity is because of resource poor farmers are very reluctant towards scientific management of crops.

\section{METHODOLOGY}

The study was carried by the KVK Betul during Kharif season 2004-05 to 2009-10(six consecutive years) in the farmers field of six adopted villages (Bhogiteda, Kolgaon, Bagholi, Dhoul, Sakadehi, Kalyanpur) of Betul district. During this six year of study as area of 31.2 ha was covered with plot size 0.4 ha under front line Demonstration with active participation of 78 Farmers. Before conducting the FLD a list of Farmers was prepared from group meeting and specific skill training was imparted to the selected farmers regarding different aspect of cultivation (Venkattakuma et al. 2010). The difference between the demonstration package and existing farmers practices are given in table-1. The soil type of area under study was medium black and light in texture with $\mathrm{PH}$. range 7.2 to 8.1.The available nitrogen phosphorus and potassium varied between 128267, 4-18 and 365-672 kg/ha respectively. However the soil is deficient in sulpher and zinc status.

In the Demonstration plot use of quality seed of improved varieties, seed treatment, timely sowing, timely weeding, need based pesticide as well as balance fertilization (Using micro nutrient Zinc and sulpher) were emphasized and comparison has been made with the existing practices of 
farmers. The necessary steps for selection of sites and farmers, layout of demonstration etc were followed as suggested by Choudhary (1999). The traditional practices were mentioned in case of local checks. The data output were collected from both FLD plots as well as control plots and finally the extension gap, technology Gap, technology index along with the benefit cost ratio were worked out (Samui et al. 2000) as given below.

Technology Gap = Potential yield-

Demonstration Yield

$$
\text { Extension Gap } \quad=\quad \text { Demonstration }
$$

Yield- Farmer Yield

$$
\text { Technology Index = } \quad \text { (Potential }
$$

Yield- Demonstration Yield)/Potential Yield

\section{RESULTS AND ANALYSIS}

The data of table -2 revealed that the yield of soybean fluctuated successively over the year in demonstration plots. The maximum yield was recorded $(20.90 \mathrm{q} / \mathrm{ha})$ during 2009-10 and minimum yield was recorded in year 2004-05 the average yield of six year was recorded $\quad 18.35 \mathrm{q} / \mathrm{ha}$ over local check $11.85 \mathrm{q} / \mathrm{ha}$.. The increase in percentage yield was ranging 33 to $82 \%$ during six year of study. On average basis 60.93 percentage increase in yield was recorded. The results are in conformity with the finding of Tomar et al. (2003), Tiwari and Saxena (2001) Tiwari et al. (2003) and Katare et al. (2011). The results clearly indicates that the positive effects of FLD over the existing practices towards enhancing the yield of soybean in Satpura plateau of M.P. with its positive effects on yield attribute (Table-3). Benefit cost ratio was recorded to be higher under demonstration against control during all the years of study. The Extension gap showing decreasing trends. The extension gap ranging between 13.62 to $22.2 \mathrm{q} / \mathrm{ha}$ during the period of study emphasized the need to educate the farmers through various means for adoption of improved agricultural production technology to reduce the trends of wide extension gap.

The trend of Technology gap (ranging between 9.10 to $17.48 \mathrm{q} / \mathrm{ha}$ ) reflects the Farmers cooperation in carrying out such demonstration with encouraging results in subsequent years. The technology observed may be attributing to the dissimilarity in soil fertility status and uncertainty of weather condition. Similar findings were recorded by Mitra et al. (2010).
The technology index showed that the feasibility of evolved technology at the farmers field. The lower value of technology index the more is the feasibility of technology. As fluctuation in technology index (Ranging between 30.33-58.27 ) during the study passed in certain region may be attributed to the dissimilarity in soil fertility, status, uncertainty of weather condition, non availability of proper insect pest management practices.

\section{CONCLUSION}

In the light of above findings it can be concluded that use of recommended scientific packages and practices of soybean cultivation can reduce the technology gap to a considerable extent thus leading to increased productivity of soybean in the district. Moreover, extension agencies of the district need to provide proper technical support to the farmers thorough different education and extension methods to reduce the extension gap for better soybean production in Betul District.

Table.1: Comparison between demonstration package and existing practices under soybean FLD.

\begin{tabular}{|c|c|c|c|}
\hline S.No & Particular & Demonstration & $\begin{array}{c}\text { Farmers } \\
\text { Practices }\end{array}$ \\
\hline 1 & $\begin{array}{c}\text { Farming } \\
\text { Situation }\end{array}$ & Rainfed & Rainfed \\
\hline 2 & Variety & JS-93-05 & JS-335 \\
\hline 3 & $\begin{array}{c}\text { Time of } \\
\text { sowing }\end{array}$ & 25 June-10 July & $\begin{array}{c}25 \text { June-10 } \\
\text { July }\end{array}$ \\
\hline 4 & $\begin{array}{c}\text { Method of } \\
\text { sowing }\end{array}$ & Line sowing & $\begin{array}{c}\text { Line } \\
\text { sowing }\end{array}$ \\
\hline 5 & $\begin{array}{c}\text { Seed } \\
\text { Treatment }\end{array}$ & $\begin{array}{c}\text { Carbendazim } 2 \mathrm{gm} / \mathrm{kg} \\
\text { seed }\end{array}$ & $\begin{array}{c}\text { No Seed } \\
\text { treatment }\end{array}$ \\
\hline 7 & $\begin{array}{c}\text { Seed rate } \\
\text { dose }\end{array}$ & $\begin{array}{c}\text { Askg/ha } \\
\text { kg/ha }\end{array}$ \\
\hline 8 & $\begin{array}{c}\text { Plant } \\
\text { Protection }\end{array}$ & $\begin{array}{c}\text { Quinalfos- Blue beetle } \\
\text { and Imidchloprid for } \\
\text { and }\end{array}$ & $\begin{array}{c}\text { Not } \\
\text { specific } \\
\text { wer acre }\end{array}$ \\
\hline 9 & $\begin{array}{c}\text { Weed } \\
\text { Management }\end{array}$ & $\begin{array}{c}\text { Imyzathyper } 1000 \mathrm{ml} / \mathrm{ha}+ \\
1 \text { daura }\end{array}$ & $\begin{array}{c}1 \text { or } 2 \\
\text { daura }\end{array}$ \\
\hline
\end{tabular}




\begin{tabular}{|c|c|c|c|c|c|c|c|c|c|c|c|}
\hline \multirow[b]{2}{*}{ Year } & \multirow[b]{2}{*}{ Area } & \multirow[b]{2}{*}{$\begin{array}{c}\text { No. of } \\
\text { Farmers }\end{array}$} & \multicolumn{3}{|c|}{ Yield (q/ha) } & \multirow{2}{*}{$\begin{array}{c}\text { Increase } \\
\text { over } \\
\text { control } \\
(\%)\end{array}$} & \multirow[b]{2}{*}{$\begin{array}{c}\text { Techno. } \\
\text { gap }\end{array}$} & \multirow[b]{2}{*}{ Ext. gap } & \multirow[b]{2}{*}{$\begin{array}{c}\text { Techno. } \\
\text { Index }\end{array}$} & \multicolumn{2}{|c|}{ B:C ratio } \\
\hline & & & Potential & Demo & Control & & & & & Demo. & Control \\
\hline 2004-05 & 5.2 & 13 & 30 & 12.52 & 7.8 & 78 & 17.48 & 22.2 & 58.27 & 2.09:1 & $1.5: 1$ \\
\hline $2005-06$ & 5.2 & 13 & 30 & 18.55 & 10.4 & 78 & 11.45 & 19.6 & 38.17 & $3.25: 1$ & $1.94: 1$ \\
\hline 2006-07 & 5.2 & 13 & 30 & 18.80 & 11.2 & 67 & 11.2 & 18.8 & 37.33 & $3.32: 1$ & $2.1: 1$ \\
\hline $2007-08$ & 5.2 & 13 & 30 & 20.39 & 11.15 & 82 & 9.61 & 18.85 & 32.03 & $3.62: 1$ & $2.1: 1$ \\
\hline 2008-09 & 5.2 & 13 & 30 & 18.94 & 14.16 & 33 & 11.06 & 15.84 & 36.87 & $3.08: 1$ & $2.59: 1$ \\
\hline $2009-10$ & 5.2 & 13 & 30 & 20.90 & 16.38 & 27.59 & 9.1 & 13.62 & 30.33 & $2.7: 1$ & $2.34: 1$ \\
\hline & 31.2 & 78 & & 18.35 & 11.85 & 60.93 & 11.65 & 18.15 & 38.83 & & \\
\hline
\end{tabular}

Table.3: Yield parameter under demonstration package and existing farmer practices.

\begin{tabular}{|c|c|c|c|}
\hline S.No & $\begin{array}{c}\text { Yield } \\
\text { Parameter }\end{array}$ & $\begin{array}{c}\text { Demonstration } \\
\text { Practices }\end{array}$ & $\begin{array}{c}\text { Existing } \\
\text { Farmer } \\
\text { Practices }\end{array}$ \\
\hline 1 & $\begin{array}{c}\text { No. of Pod } \\
\text { /plant }\end{array}$ & 91 & 76 \\
\hline 2 & $\begin{array}{c}\text { No. of } \\
\text { seed/pod }\end{array}$ & 3.2 & 2.9 \\
\hline 3 & Test wt. & $102 \mathrm{gm}$. & $96 \mathrm{gm}$. \\
\hline
\end{tabular}

\section{REFERENCES}

[1] Anonymous(2005)- Government of M.P. compendium of agricultural statistics, M.P. Agricultural Marketing Board.114 pp.

[2] Choudhary, B.N.(1999) Krishi Vigyan Kendra- A guide for KVK managers, Division of Agricultural Extension, ICAR pp. 73-78.

[3] Katare, Subhash; Pandey, S.K. and Mustafa, Mohd (2011). Yield gap analysis of Rapeseed mustard through front line demonstration. Agric. update, 6(2): 5-7.

[4] Mitra Biplab and Samajdar, T.(2010)- Yield gap analysis of rapeseed mustard through front line demonstration Agric. Exten. Review, April-June pp,16-17.

[5] Samui S.K., Mitra,S., Roy, D.K. Mandal, A.K. and Saha D.(2000), Evaluation of front line demonstration on groundnut. J. Indian Soc. Coastal Agric. Res. 18(2) 180-183.

[6] Tiwari K.B. and Saxena,A.(2001) Economic analysis of FLD of oilseed in chhindwara. Bhartiya Krishi Anusandhan Patrika 16(3\&4) 185-189.
[7] Tiwari R.B. Singh, Vinay and Parihar, Pushpa (2003), Role of FLD in transfer of gram production technology. Maharashtra J. Ext. Edu,22(1) 19.

[8] Tomer L.S. Sharma, B.P. and Joshi K. (2003) Impact of Front line Demonstration of soybean in transfer of improved technology J. Ext. Edu 22(1), 139.

[9] Venkattakumar R. Ramana Rao, S.V. Padmaiah, M. and Madhuri P.(2010) Production constraints and information needs of grower in Andhra Pradesh Agric. Extn. Review (Apr-June) pp 21-24. 